\title{
SZABADALMAK, SZABADALMI BEJELENTÉSEK ÉS TERÜLETI INNOVATIVITÁS MAGYARORSZÁGON
}

\author{
(Patents, Patent Applications and Spatial Innovativeness \\ in Hungary)
}

\section{SMAHÓ MELINDA ${ }^{1}$}

Kulcsszavak:

szabadalom szabadalmibejelentés innovativitás kutatás-fejlesztés

A tanulmány egyrészt a szellemi tulajdonjogokkal és szabadalmakkal kapcsolatos elméleti megközelítéseket adja közre, másrészi a magyarországi telepuilések innovativitásának mérésére és összehasonlítására tesz kisérletet a szabadalmi bejelentések elemzése alapján.

A tanulmány erōs pozitív korrelációt tár fel a kutatás-fejlesztési ráfordítások és a két évvel késōbb benyújtott szabadalmi bejelentések között, s több dimenzió mentén mutat ki regionális különbségeket. $A$ vidéki városok javára bekövetkezett átstrukturálódás ellenére a fôváros vezetö szerepe az âtmenet mindegyik szakaszában fennmaradt, miközben a hanyatlás jelei - az országos tendencianak megfelelöen - Budapest esetében is érzékelhetöek voltak. A városhierarchián belül éles különbségek mutatkoznak: a megyei jogú városok esetében nagyságrendbeli különbségek tapasztalhatók, vidéki viszonylatban a tradicionális egyetemvárosok emelkednek ki. A kelet-nyugat dimenzió mentén az ország keleti fele domináns.

\section{Bevezetés}

A XXI. század elején a termékek és szolgáltatások értékében egyre nagyobb arányt képviselnek az innovációk, a kutatás-fejlesztési eredmények. A nagyvállalatok innovációs versenyt folytatnak, stratégiai szövetségeket kötnek közös fejlesztéseik megvalósítására, ugyanakkor hatalmas kutatás-fejlesztési ráfordításaik megosztására, miközben a kisvállalkozásoknak csak töredéke nevezhető innovatívnak. A létrejött találmányok, felfedezések a szellemi tulajdonjogok valamely válfajának szabadalom, szerzöi jog (copyright), védjegy, ipari titok - védelme alá esnek. Köztudott tény, hogy napjainkban a modern technológiai ismeretek $80 \%$-a szabadalmi információkban koncentrálódik (Carlton-Perloff 2003; Palugyai 2004).

Hogyan alakult ki és hogyan müködik a szabadalmi rendszer? Miért van szükség a találmányok szabadalmi védettségére? Milyen kedvező és kedvezôtlen hatásai vannak a szabadalom jogintézményének? Lokalizálhatók-e a szabadalmı bejelentések, és alkalmasak-e egy térség innovativitásának mérésére? Milyen területi sajátosságokat mutattak a szabadalmi bejelentések Magyarországon az átmenet időszakában? Egyebek mellett ezek azok a fó kérdések, amelyekre e tanulmány megpróbál választ adni.

A tanulmány elsőként néhány, a szellemi tulajdonjogokkal és a szabadalom intézményével kapcsolatos elméleti megközelítést ismertet, majd azt vizsgálja, hogy a szabadalmi bejelentések száma, sủrủsége alapján mérhető-e egy térség innovativitása. 
Smahó Melinda : Szabadalmak, szabadalmi bejelentések és területi innovativitás Magyarországon.

Tér és Társadalom 19. évf. 2005/3-4. 61-79. p.

A téma újszerüségét a területi dimenzió adja, mivel Magyarországon a szerzö tudomása szerint még nem készült olyan elemzés, amely a szabadalmi bejelentéseket regionális viszonylatban vizsgálja. A hazai szakirodalomban nem állnak rendelkezésre olyan elméleti tanulmányok és empirikus vizsgálatok, amelyek akár módszertani kérdésekben, akár a regionális elemzésekben segítséget nyújthattak volna. A nemzetközi szakirodalomban nagyobb számban találhatók olyan tanulmányok, illetve könyvrészletek, amelyek a szabadalmak közgazdaságtani vonatkozásaival foglalkoznak, ám ezeknek csak töredéke tartalmaz regionális összehasonlítást (Suarez-Villa 1993; Meusburger 1998; Caniëls 2000; Greif 2001).

A különböző területi szinteken elvégzett elemzés mindenekelőtt a regionális különbségek érzékeltetésére, az abban bekövetkezett változások, és azok vélhető okainak bemutatására helyezi a hangsúlyt. A kutatás alapját egy olyan településsoros adatbázis képezi, amely a bejelentés időpontja szerint, évenkénti bontásban, a többszörös bejelentések kiszürése nélkül tartalmazza a magyarországi székhelyü/lakóhelyü bejelentők szabadalmi bejelentéseit. ${ }^{2}$ A Magyar Szabadalmi Hivatal adatai alapján összeállított adatbázis idődimenziója 1992-től 2003-ig terjed, azaz az átmenet teljes időszakát felöleli, s mind az országos tendenciák, mind a regionális különbségek feltárásához kiváló alapot szolgáltat. A tanulmány megállapításai a szakirodalom és a Magyar Szabadalmi Hivatal adatai alapján megfogalmazott hipotézisek, amelyek bebizonyítása, illetve megcáfolása további, részletesebb vizsgálatokat követel meg.

\section{Elméleti megközelítések}

A szellemi tulajdon védelme és a szabadalmaztatás intézménye több évszázados múltra tekint vissza. A haszonelvü szellemi tulajdonjog elméletek a modern állam fejlődése során alakultak ki, s a 19-20. század különféle irányzatokhoz tartozó közgazdasági gondolkodói más-más oldalról közelítették meg az innováció, a kutatás-fejlesztés, valamint az ezen tevékenységek eredményeként létrejött találmányok védelmének kérdéskörét.

\section{Szellemi tulajdonjog elméletek}

A szellemi tulajdonjog elméleteknek két nagy csoportját különböztethetjük meg, a haszonelvủ és a nem-haszonelvủ elméleteket. A haszonelvü szellemi tulajdonjog elméletek általában az innovációt elömozdító eszközként tekintik a szellemi tulajdonjogokat azzal a kitétellel, hogy ezeknek a jogoknak korlátozott az időbeli érvényessége, azért, hogy kiegyensúlyozzák a monopóliumok által okozott társadalmi jólét veszteségeket. A nem-haszonelvü szellemi tulajdonjog elméletek az utóbbi években szaporodtak el, s az alkotónak a munkájához való erkölcsi jogait hangsúlyozzák (Menell 1999).

A haszonelvủ szellemi tulajdonjog elméletek a modern állam fejlödése során alakultak ki. A szellemi tulajdonjogok a korai merkantilista periódusban bukkantak fel, 
Smahó Melinda : Szabadalmak, szabadalmi bejelentések és területi innovativitás Magyarországon.

Tér és Társadalom 19. évf. 2005/3-4. 61-79. p.

TÉT XIX. évf. 2005 -3-4

Szabadalmak, szabadalmi bejelentések ...

63

s - manufaktúrák és külföldi kereskedelmi monopóliumok létesítésén keresztül - a nemzetállam hatalma és jóléte egyesítésének és növelésének eszközeként szolgáltak. A szabadalom szó a latin patere (nyitva lenni) szóból származik, ami egy kormányzattól kapott kiváltságlevelet jelentett valamilyen mủvészet gyakorlására. Az első szabadalmi törvényt a Velencei Szenátus alkotta meg 1474-ben, a privilégium akkoriban 10 évre szólt (Menell 1999).

A szellemi tulajdon filozófiája a monopolista hatalomnak az innováció ösztönzésére való felhasználása során fejlödött ki. Adam Smith, miközben azt írta, hogy a monopolista erőfölény általában hátrányosan hat a láthatatlan kéz müködésére, elismerte, hogy az - elözetes befektetéseket és kockázatot követelö - innováció és a kereskedelem elömozdítására korlátozott monopóliumok szükségesek. John Stuart Mill (1862) arra a megállapításra jutott, hogy a szabadalmi monopóliumok jogosak, $\mathrm{s}$ ezt azzal indokolja, hogy egy átmeneti „,kizárólagos privilégium” jobb, mint egy általános kormányzati díj, mivel az elkerüli a diszkréciót, és biztosítja, hogy a feltaláló jutalma a találmány fogyasztóinak hasznosságával arányos legyen (Menell 1999).

A modern kapitalista gazdaságban a technológiai változás alapvető fontosságát Joseph Schumpeter ismerte fel, akinek a munkája három alapelvet hangsúlyozott:

- az innováció az ,alkotó rombolás" (creative destruction) következtében folyamatosan felborítja a piaci és szervezeti struktúrák fennálló kapcsolatait;

- a technológiai innováció átmenetileg monopolprofit keletkezésére ad lehetőséget, ez magyarázza a nyugati államok gyors gazdasági növekedését;

- a nagy monopóliumok a technológiai innováció elsődleges forrásai, mivel leginkább ők képesek a technológiai innováció magas költségeinek viselésére (Menell 1999).

Pigou (1924), a modern jóléti közgazdaságtan alapjainak kidolgozoja, kifejlesztette a közjavak koncepcióját: a közjavak esetében a marginális nettó privát termék kisebb, mint a marginális nettó társadalmi termék, mivel a harmadik félnek nyújtott esetleges szolgáltatásokért nehéz a fizetséget behajtani. Ugyanezt a problémát fogalmazza meg Pigou a szellemi tulajdon esetében is: a szabadalmi jognak valójában az a célja, hogy a marginális nettó privát terméket és a marginális nettó társadalmi terméket közelebb hozza egymáshoz. A bizonyos típusú találmányok esetében kilátásba helyezett jutalommal a szabadalmi jogszabályok szerinte nem ösztönzik lényegesen az egyébként többnyire spontán innovatív tevékenységet, viszont az általános hasznosság csatornáiba irányítják azt. Clark (1972) megerösítette ezt az állítást, megjegyezve, hogy egy olyan rendszer, amely nem teszi lehetővé a feltalálók számára a találmányaik feletti rendelkezést, olyan versengésbe torkollik, ahol a feltalálók inkább egymásra várnak, ahelyett, hogy megelöznék egymást a (tovább)fejlesztések létrehozásában (Menell 1999).

Az oligopólium és a tökéletlen verseny közgazdaságtana szkeptikusabb képet fest a szellemi tulajdonjogokról, s megkérdőjelezi, hogy ezek a jogok tényleg szükségesek-e a feltalálói tevékenység ösztönzéséhez. Plant azzal érvel, hogy sok felfedezés spontán, és ennél fogva szabadalmi védelem nélkül is bekövetkezik. Állítja továbbá, 
Smahó Melinda : Szabadalmak, szabadalmi bejelentések és területi innovativitás Magyarországon.

Tér és Társadalom 19. évf. 2005/3-4. 61-79. p.

hogy az első feltaláló idöbeli előnye (first-mover advantage), a piaci tökéletlenségek és más tényezők a szellemi tulajdonjogok hiányában is elegendő jutalmat adnak a feltalálóknak és a szerzőknek munkájuk megalkotásához és piacosításához. Plant arra a következtetésre jutott, hogy a szabadalmi védelem túlzott kutatás-fejlesztési beruházásokhoz vezet, ami ugyan szabadalmaztatható felfedezéseket eredményez, ám pazarlóan eltéríti a forrásokat más törekvésektỏl (Menell 1999).

Az 1960-as években a közgazdászok egyre nagyobb figyelmet fordítottak arra a kérdésre, hogy hogyan kell megtervezni a szellemi tulajdonjogokat ahhoz, hogy azok a lehető legjobban segítsék elő az innovációt. Nordhaus (1969) kimutatta, hogy a szabadalmi védelem optimális időtartama egyensúlyba hozza az innovációs ösztönzőket a monopólium holtteher-veszteségével szemben. Megállapításai között szerepel, hogy minél hosszabb a szabadalom optimális élettartama, annál kisebb a szóban forgó termék kereslet-árrugalmassága, így kisebb a találmányból származó, kutatás-fejlesztési költségekhez viszonyított társadalmi haszon, és az invenciók mennyisége érzékenyebb a kutatás-fejlesztési költségekre (Menell 1999).

Robert Solow (1957) bebizonyította, hogy 1909-1949 között a technológiai haladás és a munkaerö megnövekedett humán tơkéje nagymértékben, mintegy 80-90\%-ban járult hozzá az USA gazdaságának éves termelékenység-növekedéséhez. Dension (1985) finomította ezt az elemzést, és az 1929-1982 közötti periódust elemezve arra a megállapításra jutott, hogy a tudományos és technológiai tudás fejlődése $68 \%$-kal, a munkások képzettségének javulása $34 \%$-kal, a skálahozadék nagyobb mértékü realizálása $22 \%$-kal, a tőkeintenzitás növekedése pedig $13 \%$-kal járult hozzá a termelékenység növekedéséhez. Ezzel párhuzamosan a munkaidö csökkentése 25\%-kal, a kormányzati szabályozás pedig $4 \%$-kal csökkentette a termelékenységet. Felismerték tehát, hogy a technológiai haladás és a megnövekedett humán tőke az USA gazdasági növekedésének fö motorja (Menell 1999).

A szellemi tulajdonjogok korai formális modelljei azt feltételezték, hogy a feltalálók elzártan, nem versenyzỏ projektek formájában végezték kutatásaikat, ám az aktuális innovációs környezet ennél lényegesen összetettebb. A különbözó feltalálók (és cégek) gyakran versenyeztek az elsőségért, ami szabadalmaztatási versenyben nyilvánult meg. A közgazdászoknak ekkor bővebb, dinamikusabb modelleket kellett kifejleszteniük a rivalizáló verseny pozitív és normatív hatásainak mélyebb megértése érdekében. Barzel (1968) igazolta, hogy az innovátorok közötti, szabadalomért folytatott verseny túl gyors innovációhoz vezet, miközben a monopolista innovátor, aki nem áll szemben potenciális belépőkkel, hajlamos a túl lassú innovációra. Gilbert és Newberry (1982) kiterjesztette Barzel alapmodelljét: a szerzők rámutattak, hogy a monopolisták számára az új technológiák szabadalmaztatása a monopolista hatalom fenntartásának ösztönzöje, még mielőtt a potenciális versenytársak belépnének a piacra (Menell 1999).

A rivalizáló verseny szakirodalma a szabadalmi verseny két általános nézőpontját emeli ki: az egyik azt hangsúlyozza, hogy a rivális verseny hatékonytalanul megsokszorozza a költségeket, míg a másik nézőpont szerint a szabadalmi verseny a nagyobb beruházásokat ösztönzi. A hatékonytalansági álláspont azt emeli ki, hogy a 
Smahó Melinda : Szabadalmak, szabadalmi bejelentések és területi innovativitás Magyarországon.

Tér és Társadalom 19. évf. 2005/3-4. 61-79. p.

TÉT XIX. évf. 2005 — 3-4

Szabadalmak, szabadalmi bejelentések ...

65

kutatási költségek megduplázódása a versenyböl és a decentralizált kutatási programokból adódik. A rivális innováció externáliát produkál: miközben a kutatásfejlesztési erőfeszítések növelik a találmány kifejlesztésének és a szabadalom megszerzésének valószínúségét, a cég ezáltal csökkenti annak valószínüségét, hogy versenytársai ugyanarra a felfedezésre jussanak. Ez azonban túlzott kutatásfejlesztési beruházásokhoz vezet, amit egy európai uniós felmérés nemrégiben igazolt. Az Unióban 1990-röl 2000-re megötszöröződött a párhuzamos kutatások, ismételt feltalálások révén elpazarolt források mennyisége, ami 2000-ben körülbelül 100 milliárd eurót tett ki (Menell 1999; Palugyai 2004). Ezzel szemben a hatékonysági nézópont azt hangsúlyozza, hogy a szabadalmaztatási verseny felgyorsítja a beruházási rátát, ezáltal kikényszeríti a folyamatos haladást (Menell 1999).

A tradicionális modellek nagy része feltételezte, hogy az innováció eredménye egy végtermék vagy egy folyamat, amin már nem lehet javítani. Az idők folyamán azonban beigazolódott, hogy a legtöbb innováció nemcsak output, hanem a kreatív folyamatok inputjaként is szolgál. Isaac Newton megfogalmazása szerint „ha én tovább látok, mint mások, csak azért van, mert óriások vállán állok" (Menell 1999).

\section{A szabadalom müködési mechanizmusa}

A szabadalmi oltalom a szellemi tulajdon egyik alapvető formája, jelentős történelmi hagyományra visszatekintő, nemzetközileg rendkívül széles körben elismert és igényelt jogintézmény. A Magyar Szabadalmi Hivatal definícioja alapján: „A szabadalom a találmányok jogi oltalmát biztosítja azáltal, hogy a szabadalom tulajdonosa számára a versenytársakhoz képest elönyösebb pozíciót teremt a termékek és technológiák piacán" (www.mszh.hu).

A szabadalommal az állam meghatározott időre kizárólagos hasznosítási jogot ad a szabadalom jogosultjának a találmány tárgyára. A szabadalmi rendszer alapvető közgazdasági rendeltetése, hogy biztosítsa a kutatási és fejlesztési ráfordítások megtérülését, elömozdítsa a találmányok nyilvánosságra hozatalát és megvalósítását, valamint ösztönözze az alkotótevékenységet. Ezt az utánzás időleges tiltása révén, a jogilag védett hasznosítási pozíció megteremtésével éri el (Csiky 1999).

A szabadalmi oltalommal járó kizárólagosság időleges piaci monopolhelyzetet teremt, s ezzel lehetőséget ad arra, hogy a találmányon alapuló új termék forgalmazásával, illetve új eljárás alkalmazásával annak kifejlesztője profitot érhessen el. Oltalom híján ugyanis az új terméket utánzók, az új eljárást másolók a kifejlesztönél alacsonyabb áron kínálhatják termékeiket, hiszen az ő áruikat nem terhelik a kutatás-fejlesztés költségei. A jogi védelem hiánya valószínủleg nem szüntetné meg az alkotószenvedélyből táplálkozó feltalálói tevékenységet, ám a szabadalmi oltalom által nyújtott ösztönzés nélkül - felmérések szerint - a találmányoknak mintegy egyharmada-egynegyede soha nem születne meg. Pl. a gyógyszeriparban nagy jelentösége van a szabadalmaztatásnak: szabadalmi védettség nélkül a gyógyszerek 65\%-a nem kerülne piacra, 60\%-a pedig nem lenne kifejlesztve (Csiky 1999; A gyógyszerpiac szabályozásának... 2003). 
Smahó Melinda : Szabadalmak, szabadalmi bejelentések és területi innovativitás Magyarországon.

Tér és Társadalom 19. évf. 2005/3-4. 61-79. p.

A szabadalom hátránya, hogy hatékonytalanságot teremt, mivel lehetőséget ad a piac szeparálására, a védett termék országok közötti szabad forgalmazásának akadályozására. Piaci hatalmat hoz létre, s ezzel megteremti annak lehetőségét, hogy a szabadalommal védett terméket a vállalat határköltség feletti áron kínálja, ami társadalmi veszteséget is eredményez (A gyógyszerpiac szabályozásának... 2003).

\section{Szabadalom vagy üzleti titok?}

Ha egy találmány potenciális gazdasági értékkel rendelkezik, akkor valamilyen formában védelmezni kell a jogosulatlan felhasználókkal szemben. Ebben a helyzetben - a találmány típusától függően - általában két alternatíva kínálkozik: vagy szabadalmaztatásra kerül a találmány, vagy üzleti titok tárgyát képezi. A titokban tartott felfedezés esetén azonban a találmány tulajdonosa nincs biztosítva a véletlen, töle független felfedezések ellen. A döntés során általában több tényezö is mérlegelésre kerül, amelyek alapján kirajzolódik a nem szabadalmaztatás néhány tipikus esete (Basberg 1987).

1) A találmány a szabadalmi törvény értelmében nem szabadalmaztatható. A szabadalmi jog országról országra változik, Magyarországon „,szabadalmazható minden új, feltalálói tevékenységen alapuló, iparilag alkalmazható találmány a technika bármely területén". Nem minösül azonban találmánynak a felfedezés, a tudományos elmélet és a matematikai módszer, az esztétikai alkotás, a szellemi tevékenységre, játékra, üzletvitelre vonatkozó terv, szabály vagy eljárás, valamint a számítógépi program és az információk megjelenítése. A felsoroltak szabadalmazhatósága csak annyiban kizárt, amennyiben a szabadalmat rájuk kizárólag e minöségükben igénylik (Basberg 1987; A 2002. évi XXXIX. törvénnyel módosított...).

2) Bizonytalanság. Az új technológiák (mikroelektronika, biotechnológia) esetében gyakori a bizonytalanság, ezért a feltaláló sokszor titokban tartja a felfedezést (Basberg 1987).

3) Gazdasági elvárások. Általánosságban megállapítható, hogy a szabadalmaztatási eljárás magas költségei miatt a bejelentők csak a kedvezỏ profitkilátásokkal rendelkező találmányok szabadalmaztatását kezdeményezik. Ugyanakkor az egyéni feltalálók, illetve a kisvállalkozások egy része - a magas költségek miatt - nem képes arra, hogy találmányát szabadalmaztassa. A gazdasági elvárások másik dimenzióját a találmányból származó profit várható nagysága adja. Ha az elvárt jövedelem bizonytalan, vagy kisebb, mint a szabadalmaztatási eljárás költségei, akkor a találmány valószínüleg titokban marad.

A feltalálók rendszerint abban az országban jelentik be a szabadalmat, ahol a védelemre szert szeretnének tenni, azaz fordulhatnak a nemzeti szabadalmi hivatalukhoz, valamint lehetóségük van ún. regionális szabadalmi hivataloknál való bejelentésre, mint amilyen például az Európai Szabadalmi Hivatal. A világ három legnagyobb szabadalmi rendszere az európai (European Patent Office, EPO), az amerikai (United States Patent and Trademark Office USPTO) és a japán (Japanese Patent Office JPO) szabadalmi rendszer. Ezen 
Smahó Melinda : Szabadalmak, szabadalmi bejelentések és területi innovativitás Magyarországon.

Tér és Társadalom 19. évf. 2005/3-4. 61-79. p.

TÉT XIX. évf. 2005 - 3-4

Szabadalmak, szabadalmi bejelentések ...

67

kívül létezik egy ún. triád rendszer, amely azon szabadalmaztatott találmányokat tartalmazza, amelyek az előbb említett három fó szabadalmi rendszer, illetve hivatal mindegyike által védve vannak. A triád rendszerben elsősorban azokat a szabadalmakat jelentik be, illetve jegyzik, amelyeknek valószínűsíthetően nagy lesz a kereskedelmi értéke, mivel mindhárom rendszerben állni kell a szabadalmaztatás költségeit. Ezért ebböl a rendszerböl elsősorban a nagyvállalatok szabadalmaztatási aktivitására következtethetünk, akik szélesebb nemzetközi védelmet igényelnek, és ezt meg is engedhetik maguknak (Basberg 1987).

4) Versenytársak. Jellemzöen a találmány titokban tartása mellett döntenek a vállalatok akkor is, ha attól tartanak, hogy - a szabadalmaztatási eljárás során kötelező nyilvánosságra hozatal révén - az információk versenytársaik tudomására jutnak. A konkurens cégek pedig egy kis módosítással újra szabadalmaztathatják a találmányt, aminek következtében az eredeti feltalálónál felmerült kutatás-fejlesztési költségek nem térülnek meg, mivel ez esetben az alapötletet módosító vállalat realizálja a profitot, miközben az eredeti feltaláló monopol pozíciója megszünik, profitja csökken. Az „újra szabadalmaztatás" a versenytársaknál nem okoz akkora fejlesztési költséget, mint amekkora kutatás-fejlesztési ráfordítások az eredeti feltalálónál jelentkeztek. A költségtényező ilyen esetben tehát nem jelent hatékony korlátot, $\mathrm{s}$ a szabadalom csak néhány hónappal késleltetné az utánzást, ezért haszontalan (Basberg 1987; Meusburger 1998; Carlton-Perloff 2003).

5) A találmány elvárt gazdasági élettartama. A szabadalom értéke attól függ, hogy mennyi idôre biztosít exkluzív jogokat a gyártáshoz és forgalmazáshoz. Bár a nemzetközileg elfogadott szabadalmi idő 20 év, az effektív védettség ennél sokkal rövidebb, ugyanis a szabadalom kezdete, a levédés és a piacra kerülés között - országonként különbözö, de átlagban - 5-10 év, esetenként $12-13$ év is eltelik. A piacra kerülés után kiaknázható szabadalmi idő így jelentösen lecsökken. A kiegészítő szabadalmi oltalom intézménye lehetövé teszi az eredeti 20 éves szabadalmi időszaknak - az alapszabadalom lejárati idôpontjától számított - maximum 5 éves kiterjesztését, amennyiben az nem növeli 15 évnél hosszabbra a forgalomba kerülési időt.

Ha tehát a termék elvárt élettartama sokkal hosszabb, mint a szabadalom maximális élettartama, akkor nem érdemes szabadalmaztatni, mert a szabadalmi eljárás során nyilvánosságra kerül a találmány leírása, s a szabadalmi védelem lejártával bárki szabadon gyárthatja, forgalmazhatja a terméket. A feltaláló vagy a jogosult tehát jobban jár, hogyha titokban tartja a felfedezést. Ha a termék élettartama nagyon rövid - sokkal rövidebb, mint a szabadalmi oltalom maximális élettartama -, akkor is érdemes titokban tartani a felfedezést. Jó példaként szolgálnak erre az esetre a gyorsan újitó iparágak (számítástechnika, mikroelektronika), mivel ezeken a területeken fennáll a veszély, hogy a találmány elavul, még mielött a szabadalmat megadnák. A gyorsaság pedig nagyobb előnyt jelent a szabadalmi oltalomnál (Basberg 1987; A gyógyszerpiac szabályozásának... 2003). 
Smahó Melinda : Szabadalmak, szabadalmi bejelentések és területi innovativitás Magyarországon.

Tér és Társadalom 19. évf. 2005/3-4. 61-79. p.

Mindezek mellett a szabadalmaztatás kérdése szektorspecifikus tényező is, a szabadalmak jelentősége, valamint a találmányok bejelentésére való hajlandóság gazdasági ágak, vállalatméret és más tényezök szerint változik. Egyes iparágak szabadalmaztatási hajlandósága (propensity to patent) magasabb, míg másoké alacsonyabb. A szabadalmaztatási hajlandóság egy szervezet, iparág stb. szabadalmainak száma és $\mathrm{K}+\mathrm{F}$ kiadásainak hányadosaként értelmezhetö, $\mathrm{s}$ kizárólag az adott vonatkoztatási egységek (területek, ágazatok stb.) egymással való összehasonlítására szolgál. A gyorsan újító iparágak (pl. számítástechnika, elektronika) szabadalmaztatási hajlandósága jellemzően alacsony, mivel itt a gyorsaság, az időbeli előny (lead time) hatékonyabb védelmet és nagyobb gazdasági előnyt jelent, mint a több évig elhúzódó eljárás végén megkapott szabadalom. A szabadalom megszerzésének időpontjában ugyanis az adott újítás már elavulttá válik, s így piaci értékkel sem rendelkezik. A hadiiparban a katonaság által megkövetelt titoktartás miatt szintén jóval kevesebb találmány kerül bejelentésre és szabadalmaztatásra, mint amennyi meszületik. Az alacsony szabadalmaztatási hajlandóság másik oka lehet az, hogy a $\mathrm{K}+\mathrm{F}$ ráfordítások eredménye nem szabadalom, hanem más oltalmi forma vagy szerzői jog alakjában ölt testet (Caniëls 2000; Meusburger 1998).

\section{Az innovativitás mérése}

Az innováció, a folyamatos technológiai megújulás a XXI. század elejên minden eddiginél fontosabb szerepet játszik a fejlődésben, a versenyképesség megörzése és javítása tekintetében. Egy ország, illetve azon belül egy földrajzi terület innovativitásának mérése meglehetősen nehéz feladat, mivel nem áll rendelkezésünkre olyan mutatószám, amelynek segítségével a megújulási képesség közvetlenül kifejezhetỏ és összehasonlítható. Kérdöíves felmérések és statisztikai adatok alapján megbecsülhető az innovatív vállalkozások száma, ám ezek az adatok sem a vállalatok innovációs tevékenységének intenzitását, sem a magánszemélyek újitási aktivitását nem fejezik ki.

Az innovativitás területi dimenzióban történỏ mérésének egyik lehetséges módja a szabadalmi bejelentések számának vizsgálata. A szabadalmi bejelentés egy találmány létét feltételezi, ami tudást, ötletet, kreativitást foglal magában. Ennélfogva a szabadalmi bejelentések területi eloszlásából a tudás, a megújulás egyfajta megnyilvánulásának földrajzi elhelyezkedésére, sủrủsödési helyeire, koncentrációira következtethetünk. A szabadalmi bejelentések az egyéni és vállalati feltalálói tevékenységet egyaránt tükrözik, ugyanakkor az innovativitás mértékéről, hozzávetőleges nagyságrendjérỏl is információt nyújtanak. Meusburger (1998) átfogó müvében a szabadalmi bejelentések száma, mint innovativitást mérő mutató alkalmazásának számos elönyét és hátrányát sorakoztatja fel. Mesburger - több más szerzỏ álláspontjára való tekintettel - arra a következtetésre jut, hogy a felmerülỏ módszertani problémák ellenére a szabadalmi adatok elemzése nagytérségek esetében jól használható a kutatási eredmények és a feltalálói magatartás területi különbségeinek elemzésére akkor, ha az adatok értelmezése a térségi kutatási potenciál és kutatási infrastruktúra, valamint a regionális gazdasági struktúrák figyelembevételével tör- 
Smahó Melinda : Szabadalmak, szabadalmi bejelentések és területi innovativitás Magyarországon.

Tér és Társadalom 19. évf. 2005/3-4. 61-79. p.

TÉT XIX. évf. 2005 — 3-4

Szabadalmak, szabadalmi bejelentések ...

69

ténik. A szabadalmi adatok ugyanis magas korrelációt mutatnak az innovatív tevékenységek más mérőszámaival (kutatás-fejlesztési kiadások és beruházások, kutatás-fejlesztésben foglalkoztatottak aránya) (Meusburger 1998).

A nem szabadalmaztatás - korábban említett - eseteitöl eltekintve azt mindenestre leszögezhetjük, hogy egy találmány esetében a szabadalmi bejelentés elkészítése és benyújtása - $\mathrm{s}$ ezzel a szabadalmaztatási eljárás megindítása - jelentős újítás keletkezésére enged következtetni. A bejelentönek egyszeri és folyamatos dijat kell fizetnie az eljárásért és a szabadalom fenntartásáért, ami egyértelmủen bizonyítja, hogy a bejelentónek érdekében áll a felfedezés alkalmazása. A szabadalmi bejelentések adatai a benyújtott, de időközben a dífizizetés hiánya miatt megszünt kérelmeket is magukban foglalják, tehát ennyivel is pontosabb képet festenek az adott terulet innovativitásáról. A létrejött találmányok és a szabadalmi bejelentések száma eltér egymástól, mivel a találmányoknak csak egy része kerül szabadalmaztatásra. A megadott szabadalmak pedig a szabadalmi bejelentések részhalmazát képezik, hiszen nem minden bejelentés esetében ítélik meg az oltalmat.

Egy területi egység innovativitásának szabadalmi bejelentések alapján való becslése, mérése során felmerül a szabadalmi bejelentések lokalizálásának problémája. A feltaláló és a bejelentö (jogosult) személye nem feltétlenül azonos, aminek következtében földrajzi elhelyezkedésük is különböző lehet. A szakirodalom és a szabadalmi adatbázisok alapján mind a feltaláló, mind a bejelentő székhelye/ lakóhelye szerint lokalizálhatóak a bejelentések, azonban mindkét esetben jelentkezik némi pontatlanság. Egy találmánynak általában több tulajdonosa, gyakran több feltalálója is van, ilyen esetben a szabadalmi bejelentés mindegyik feltaláló/bejelentő lakóhelyéhez hozzá van rendelve (többszörös bejelentés). A szabadalmi bejelentések földrajzi helyhez kötésének másik fö problémája a vállalatok székhelyének és telephelyének eltérő földrajzi elhelyezkedése. Ebben az esetben a regionális GDP számításánál is jelentkező módszertani problémával találkozunk: az esetenként több telephellyel is rendelkező (nagy)vállalatok székhelyük szerinti helymegjelöléssel adják be a szabadalmi bejelentéseket, ám lehetséges, hogy a felfedezés a vállalat - földrajzilag máshol, gyakran más országban elhelyezkedö telephelyén keletkezett.

Bár a találmány megalkotója a feltaláló, az újítás mégis a tulajdonosoknál kamatozik, ők hasznosítják, s ilyen értelemben a szabadalmi bejelentés benyújtásától kezdődően a találmány a bejelentőhöz kötődik. A szakirodalomban a feltaláló és a bejelentő székhelye/lakóhelye alapján végzett elemzések egyaránt megtalálhatók, sőt fellelhetö olyan elemzés is, amely azt állítja, hogy bizonyos területi szinten nincs számottevő különbség a feltaláló és a bejelentő székhelye/lakóhelye alapján végzett vizsgálat eredményei között (Greif 2001).

Jelen tanulmány a bejelentő székhelye/lakóhelye alapján lokalizálja a szabadalmi bejelentéseket. Magánfeltalálók esetében a feltaláló és a bejelentő jellemzỏen ugyanaz a személy, így a bejelentő lakóhelye megegyezik a tudás keletkezésének helyével. A vállalati és intézményi bejelentők esetében a munkavállalók (feltalálók) lakóhelye és a szabadalmat bejelentő szervezetek székhelye nem feltétlenül azonos, ám a tudás 
Smahó Melinda : Szabadalmak, szabadalmi bejelentések és területi innovativitás Magyarországon.

Tér és Társadalom 19. évf. 2005/3-4. 61-79. p.

ettől függetlenül a vállalatnál keletkezik, $s$ ott is jelenik meg szabadalmi bejelentés formájában, mivel szolgálati találmány esetén a szabadalom a munkáltatót illeti meg. ${ }^{3}$

A szabadalmi bejelentések településnél magasabb területi szinteken való elemzése során merül fel az aggregálás problémája. Egyrészt a feltalálók/jogosultak nem feltétlenül azonos arányban részesei a szabadalomnak, ezért a tulajdoni hányadokat figyelembe kellene venni az aggregálás során. Másrészt pedig tekintettel kell lenni arra, hogy a települési szintủ adatok összesítésével a - több feltaláló/bejelentő miatt települési szinten is elöforduló - halmozódás a magasabb területi szinteken fokozódik, aminek következtében egyre távolabb kerülünk a szabadalmi bejelentések valós darabszámától, miközben a feltalálók/bejelentők számát egyre pontosabban megközelítjük. Magasabb területi szinteken (megye, régió) tehát már nem a szabadalmi bejelentések pontos számára kell az elemzésnek koncentrálnia, hanem az emögött rejló szellemi potenciálra, és annak az azonos szintủ területi egységek közötti különbségeire.

\section{Szabadalmi bejelentések Magyarországon}

\section{Szabadalmi bejelentések országos tendenciái}

Az 1990-es évtizedben országos szinten jelentős hanyatlás következett be a szabadalmi bejelentések számában. A visszaesés mértékét jól érzékelteti, hogy az 1998-ban benyújtott szabadalmi bejelentések száma az 1992. évben tett bejelentések $47 \%$-át tette ki, a beadványok száma tehát kevesebb, mint felére csökkent. 2003-ban - néhány év átmeneti növekedés után - még a kilencvenes évek mélypontjának minősülő 1998. évinél is kevesebb szabadalmi bejelentést nyújtottak be, az 1992. évinek mindössze 39\%-át. A szabadalmi bejelentések számának csökkenése mögött vélhetően többféle ok, illetve ezek eredöje húzódik meg. A kilencvenes évek első felében a rendszerváltás hatása tükrözödik a szabadalmi bejelentések számának csökkenésében, míg a 2001. évben kezdődött csökkenő tendenciát 2003-tól jogszabályi változások erősítik fel ${ }^{4}$ (Éves jelentés 2004).

A rendszerváltás alapjaiban rázta meg az országot, a gazdaságot és a társadalmat, ami mind az intézményi, mind az egyéni bejelentések számának alakulására kihatással volt. A szabadalmi bejelentések számának alakulását közvetlenül fóként a kutatásfejlesztési kiadások befolyásolják, annál is inkább, mivel a múlt században bekövetkezett fordulat eredményeként a napjainkban érvényben levő szabadalmak több, mint fele intézményi bejelentők tulajdonában van, s a statisztikai adatok között fellelhető kutatás-fejlesztési ráfordítások csak az állami és vállalati ráfordításokat - tehát az intézményi bejelentök K+F kiadásait - tartalmazzák (Suarez-Villa 1993).

Szakirodalmi források és az adatok elemzése során felhalmozódott tapasztalatok egyaránt alátámasztják a $\mathrm{K}+\mathrm{F}$ kiadások és a - néhány évvel később benyújtott szabadalmi bejelentések száma közötti pozitív korreláció létezését (Basberg 1987; Greif 2001). Magyarországon az adott évi - változatlan árakon számított - K+F ráfordítások és a 2 évvel később benyújtott szabadalmi bejelentések száma között mutatható ki erös kapcsolat: az 1992-2002 közötti időszakban a determinációs 
Smahó Melinda : Szabadalmak, szabadalmi bejelentések és területi innovativitás Magyarországon.

Tér és Társadalom 19. évf. 2005/3-4. 61-79. p.

TÉT XIX. évf. 2005 -3-4

Szabadalmak, szabadalmi bejelentések ...

71

együttható értéke 0,8657 , ami azt jelenti, hogy a kutatás-fejlesztési ráfordítások 86,6\%-ban magyarázzák meg a 2 évvel később benyújtott szabadalmi bejelentések szórását. A korrelációs együttható az 1992-2002 közötti időszakban 0,93-as értéket vett fel, ami nagyon szoros kapcsolatra utal a kutatás-fejlesztési ráfordítások és a 2 évvel később benyújtott szabadalmi bejelentések között. 1992 és 2003 között kissé alacsonyabb $(0,8)$ a korrelációs együttható értéke, ami azzal magyarázható, hogy 2002 után - a szabadalmi bejelentések számának drasztikus csökkenése miatt - úgy tünik, kinyílik az olló a két adatsor között (1. ábra).

1. ÁBRA

$K+F$ ráfordítások és a 2 évvel késöbb benyújtott

szabadalmi bejelentések számának alakulása 1992-2003

( $R \& D$ Expenditure and Patent Applications Submitted 2 Years Later, 1992-2003)

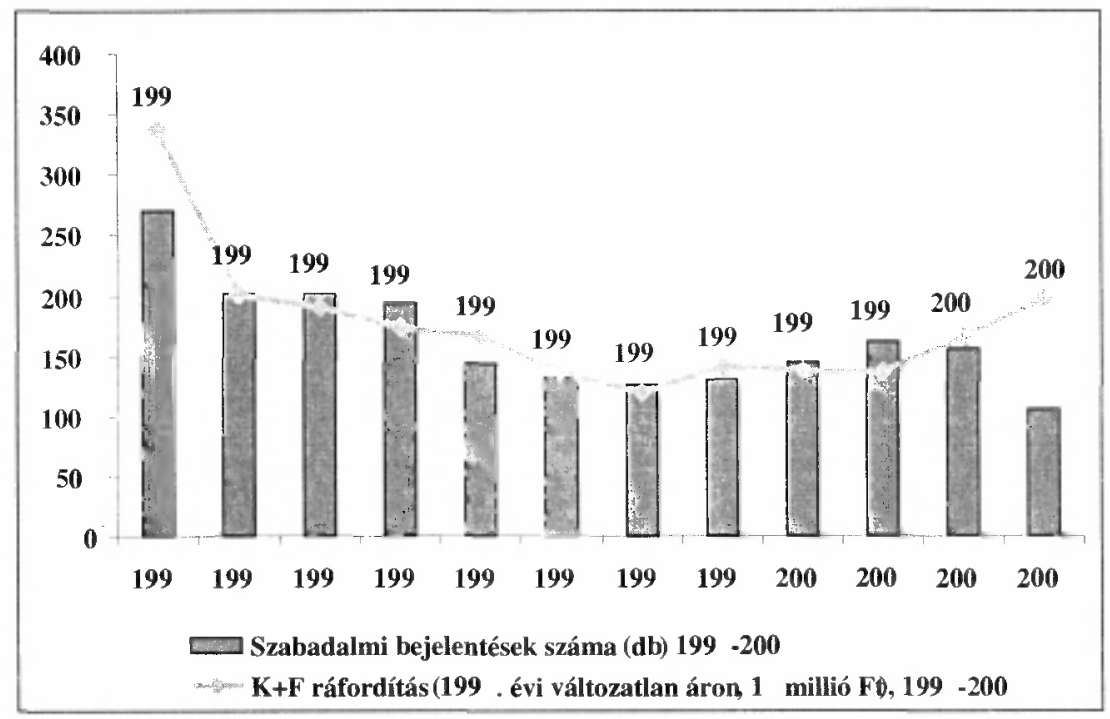

Megjegyzés: Az ábrán a két változó egyiuttes ábrázolásához azonos nagyságrendủ adatokra volt szükség, ami a $\mathrm{K}+\mathrm{F}$ ráfordítások 10 millió forintos mértékegységben való mérésével oldható meg.

Forrás: Saját szerkesztés. Az adatok forrása: Magyar Iparjogvédelmi és Szerzői Jogi Egyesület keretében működő munkabizottság jelentése ..., KSH, Magyar Szabadalmi Hivatal.

A rendszerváltást követỏen a változatlan áron számított kutatás-fejlesztési ráfordítások jelentős visszaesése volt tapasztalható. Az 1996. évi mélypont után három év stagnálás következett, majd az ezredforduló környékén indult el a $\mathrm{K}+\mathrm{F}$ ráfordítások számottevőnek tekinthető növekedése. A kilencvenes évek első felében a vállalati és az állami szférában egyaránt beszükültek a kutatás-fejlesztés forrásai, csökkent a kereslet a hazai kutatások iránt, a kutatás-fejlesztési kapacitásoknak csak töredéke maradt meg. A vállalatok, kutatóintézetek létszámcsökkentéseket hajtottak végre, a vállalati átalakításoknak, átszervezéseknek elsőként a termelésben közvetlenül részt nem vevő kutatás-fejlesztési részlegek estek áldozatul. Óriásvállalatok hullottak szét, 
Smahó Melinda : Szabadalmak, szabadalmi bejelentések és területi innovativitás Magyarországon.

Tér és Társadalom 19. évf. 2005/3-4. 61-79. p.

az átszervezések és tulajdonosváltások következtében a vállalati kapcsolatok átmenetileg szétszakadtak, majd megváltozott formában tovább éltek, illetve újra kialakultak. Az egyetemeken tömegessé vált az oktatás, egyre kevesebb pénz és idő jutott kutatásra (Barta 2002; Döry-Rechnitzer 2000; Döry-Mészáros-Rechnitzer 1998).

A vállalati és állami kutatás-fejlesztés hanyatlásával párhuzamosan romlott az ország lakosságának életszínvonala, tömegessé vált a munkanélküliség, a keresetek reálértéke csökkent. Ezek a tényezők vélhetöen kedvezötlenül érintették a magánfeltalálók helyzetét és szabadalmaztatási tevékenységét, aktivitásukat az eljárás költségeinek jelentős emelkedése tovább rontotta.

A kilencvenes évtized második felében már az élénkuilés, az újraéledés jelei mutatkoztak. Fejlesztő văllalkozások jöttek létre, az évek folyamán egyre több kủlföldi tőke $-\mathrm{s}$ vele együtt a magyarországi high-tech jelentős része - érkezett az országba, hazánkban is megjelent az innovációorientált vállalati magatartás. A vállalati kutatóhelyeken dolgozó szakemberek száma 1996 és 2001 között kétszeresére nőtt. Az évtized közepétől újra növekedésnek indultak a kutatás-fejlesztési ráfordítások, ami 2001-ig maga után vonta a szabadalmi bejelentések számának lassú növekedését (Barta 2002; http://www.unkari.fi).

\section{Regionális különbségek az átmenet éveiben}

Míg a szabadalmi bejelentések hosszú idősorainak elemzése a technológiai változás mérésére, jellemzőinek leírására ad lehetőséget, addig a szabadalmi bejelentések regionális adatai alapján az egyes földrajzi területek (települések, megyék, régiók) innovativitására lehet következtetni. A szabadalmi bejelentések nagyságrendje és területi eloszlása az átmenet egyes időszakaiban meglehetősen differenciált képet mutat. A föbb területi folyamatok, tendenciák feltárása érdekében az elemzést célszerü több dimenzió mentén is elvégezni, mindenekelőtt a regionális tudományban klasszikusnak számító föváros-vidék, város-vidék és kelet-nyugat tagoltság figyelembevételével.

A regionális különbségek fontos dimenzióját jelentik a településhierarchiában fellelhetỏ eltérések, az egyes jellemzóknek bizonyos településtípusokban való koncentrációi. A szabadalmi bejelentések esetében főváros-vidéki városok, valamint vidéki városok-egyéb települések viszonylatában teszünk kísérletet a területi különbségek kimutatására, elemzésére.

A szabadalmi bejelentések területi különbségeinek vizsgálata során elsöként $B u d a$ pest szerepét kell kiemelni, hiszen az elmúlt évtizedben a szabadalmi bejelentések több mint fele - 52-57\%-a - a fővárosban koncentrálódott. 2003-ra Budapest részaránya $47 \%$-ra csökkent, miközben a vidéki városok a szabadalmi bejelentések egyre nagyobb hányadát adták. A nem városi települések szabadalmi bejelentésekből való részesedése mindőssze 1-2\%-kal növekedett a kilencvenes évek folyamán, tehát kimutatható, hogy a vidéki városok részarányának növekedése Budapest rovására következett be (1. táblázat). 
Smahó Melinda : Szabadalmak, szabadalmi bejelentések és területi innovativitás Magyarországon.

Tér és Társadalom 19. évf. 2005/3-4. 61-79. p.

TÉT XIX. évf. 2005 - 3-4

Szabadalmak, szabadalmi bejelentések ...

73

\section{TÁBLÁZAT}

A szabadalmi bejelentések településtípusonkénti megoszlása (\%), 1992-2003

(Distribution of Patent Applications in the Different Settlement-Types (\%),

1992-2003)

\begin{tabular}{ccccc}
\hline Év & $\begin{array}{c}\text { Városok } \\
\text { száma } \\
(\mathrm{db})\end{array}$ & $\begin{array}{c}\text { Szabadalmi } \\
\text { bejel. aránya } \\
\text { Budapesten (\%) }\end{array}$ & $\begin{array}{c}\text { Szabadalmi } \\
\text { bejel. aránya a } \\
\text { városokban (\%)* }\end{array}$ & $\begin{array}{c}\text { Szabadalmi bejel. } \\
\text { aránya a nem városi } \\
\text { településeken }\end{array}$ \\
\hline 1992 & 180 & 57 & 33 & 10 \\
1993 & 194 & 54 & 35 & 11 \\
1994 & 194 & 52 & 36 & 12 \\
1995 & 200 & 53 & 35 & 12 \\
1996 & 206 & 54 & 35 & 11 \\
1997 & 218 & 55 & 33 & 12 \\
1998 & 218 & 52 & 36 & 12 \\
1999 & 222 & 56 & 32 & 12 \\
2000 & 237 & 49 & 39 & 12 \\
2001 & 252 & 46 & 41 & 13 \\
2002 & 252 & 49 & 40 & 11 \\
2003 & 256 & 47 & 40 & 13 \\
\hline
\end{tabular}

* Budapest nélkül

Forrás: Saját szerkesztés a Magyar Szabadalmi Hivatal adatai alapján.

A vidéki városok súlyának emelkedéséhez mindenképpen hozzájárult a városok számának 1992 és 2003 közötti 42\%-os növekedése. A városok számának emelkedése, s ezzel az urbanizáció és a migráció hatásainak felerősödése következtében a magyarországi városállomány humántőke-állománya, a találmányok keletkezésének legfontosabb forrása, számottevően gyarapodott.

A kilencvenes években a Budapesten kívüli, vidéki városokból származó szabadalmi bejelentések 50-60\%-a a megyei jogú városokban koncentrálódott, amiböl egyértelmüen következik, hogy különbséget kell tennünk a városhierarchia eltérö fokán álló települések között. A megyei jogú városok központi funkciót töltenek be az egyes térségekben, vidéki viszonylatban ezek a települések integrálják a legjelentősebb felsőoktatási és kutatás-fejlesztési kapacitásokat, tudásbázisokat.

A szabadalmi bejelentések területi elhelyezkedése az átmenet egyes időszakaiban más-más sajátosságokat mutat. 1992-ben, az átalakulás kezdetén differenciált kép rajzolódik ki a szabadalmi bejelentések területi eloszlását illetően (2. ábra). Ebben az évben az ország 237 településéhez kapcsolódott szabadalmi bejelentés, ám ezeknek közel 60\%-át budapesti bejelentők nyújtották be. A fövárost és agglomerációját együittesen tekintve még erőteljesebb koncentráció valószínűsíthető, hiszen a Budapestet övező települések szinte mindegyikéröl nyújtottak be szabadalmi bejelentést. Budaörs és Gödöllő szabadalmi bejelentéseinek nagyságrendje néhány megyei jogú város - Györ, Székesfehérvár, Kaposvár, Eger, Nyíregyháza - potenciáljával azonos szintủnek minősíthető. 
Smahó Melinda : Szabadalmak, szabadalmi bejelentések és területi innovativitás Magyarországon.

Tér és Társadalom 19. évf. 2005/3-4. 61-79. p.

TÉT XIX. évf. 2005 -3-4

\section{2. ÁBRA}

Szabadalmi bejelentések száma településenként (db), 1992

(Patent Applications in Settlements [Piece], 1992)

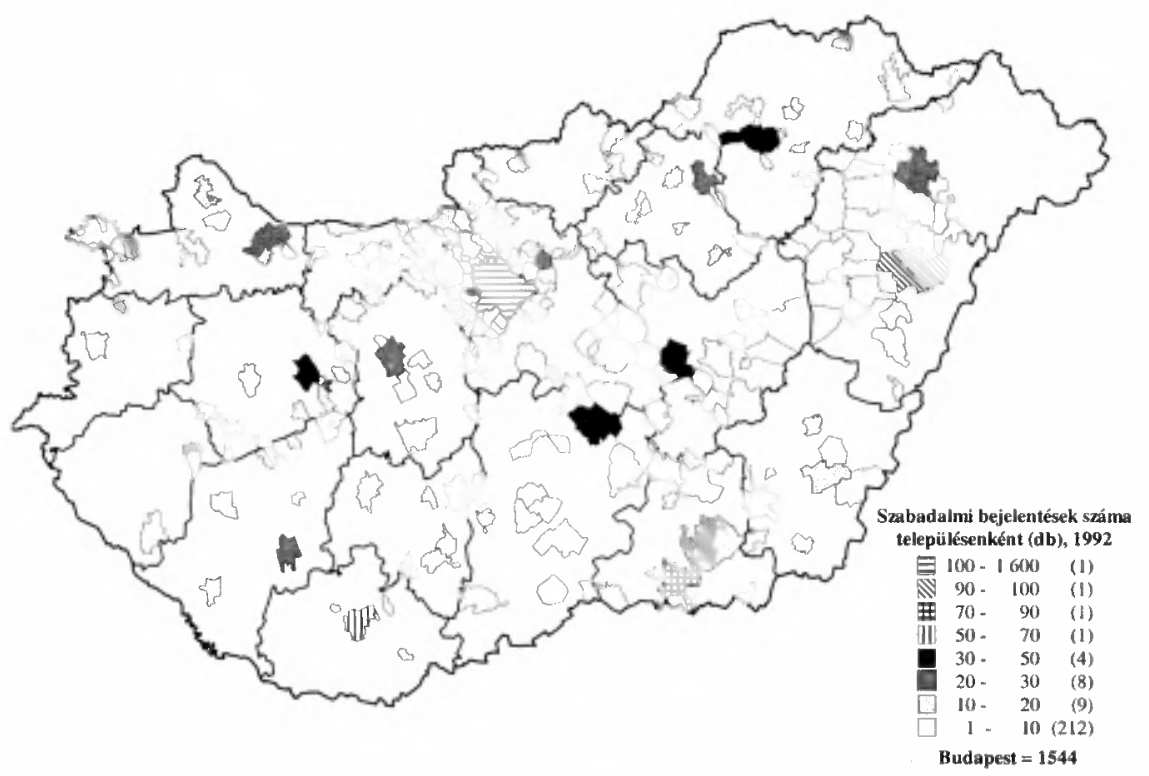

Forrás: Saját szerkesztés a Magyar Szabadalmi Hivatal adatai alapján.

A vidéki városok közül a nagy egyetemvárosok - Debrecen, Szeged, Pécs - emelkednek ki, ahonnan 1992-ben 95, 71, illetve 60 szabadalmi bejelentés származott. A városok következö csoportját Miskolc, Szolnok, Kecskemét és Veszprém képezi, itt a szabadalmi bejelentések száma 30 és 50 közé esett a vizsgált évben. A megyei jogú városok közül Györ, Székesfehérvár, Kaposvár, Eger és Nyíregyháza alkotja a következő kategóriát 20 és 30 közötti bejelentésszámmal. Mindezek alapján megállapítható, hogy nemcsak a fóváros és a vidéki városok, valamint a megyei jogú városok és a többi város között fedezhetök fel jelentős eltérések, hanem a megyei jogú városok között is számottevő nagyságrendbeli különbségek tapasztalhatók. A Dunát választóvonalnak tekintve egyértelmúen látszik, hogy a szabadalmi bejelentések tekintetében az ország keleti fele a hangsúlyosabb.

A szabadalmi bejelentések számának a 90-es években bekövetkezett csökkenése 1998-ban érte el a mélypontját, ekkor az országnak mindössze 175 településéröl nyújtottak be szabadalmi bejelentést. Az évtized eleji éles területi különbségek elhalványultak. Budapest vezető szerepe továbbra is megmaradt, ám szabadalmi bejelentéseinek száma az országos tendenciánál erőteljesebben csökkent, az 1992. évi bejelentésszám $43 \%$-ára esett vissza. 
Smahó Melinda : Szabadalmak, szabadalmi bejelentések és területi innovativitás Magyarországon.

Tér és Társadalom 19. évf. 2005/3-4. 61-79. p.

TÉT XIX. évf. 2005 — 3-4

Szabadalmak, szabadalmi bejelentések ...

\section{3. ÁBRA}

Szabadalmi bejelentések száma településenként (db), 1998

(Patent Applications in Settlements [Piece], 1998)

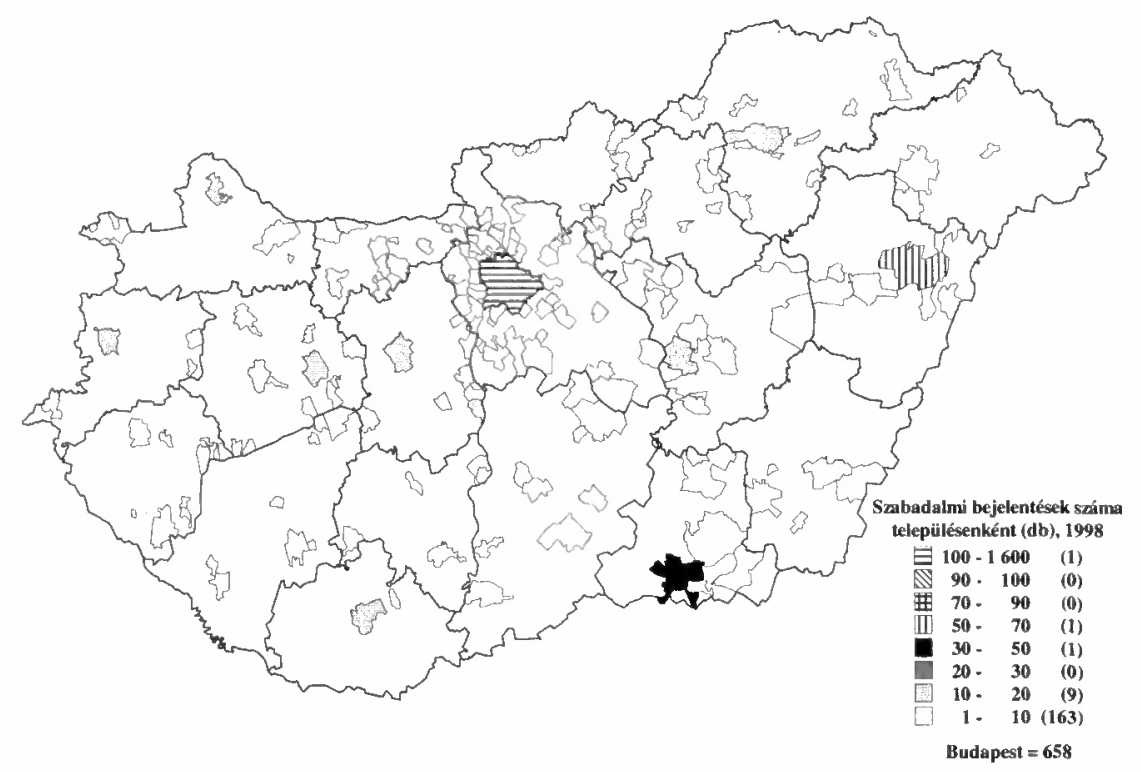

Forrás: Saját szerkesztés a Magyar Szabadalmi Hivatal adatai alapján.

A főváros körüli agglomerációs gyürü továbbra is megmaradt, azonban itt is jelentős csökkenés következett be a szabadalmi bejelentések számában (3. ábra). Az 1992-ben még jelentős szabadalmaztatási aktivitással rendelkező nagyvárosok pozíciója nagyságrendekkel romlott, közülük mindössze Debrecen és Szeged emelkedett ki 53, illetve 38 bejelentéssel, ami az 1992. évi értékeiknek alig több mint felét tette ki. A szabadalmi bejelentések egész országra kiterjedő drasztikus csökkenése mellett továbbra is fennmaradt az ország keleti felének dominanciája.

2002-ben - az 1998. évi mélyponthoz viszonyítva - növekedett a szabadalmi bejelentések és a szabadalmi bejelentéssel rendelkezö települések száma. Jelentösen javult Szeged, Miskolc és Pécs pozíciója, ám ebben az évben még egyik említett város sem érte el az évtized eleji szintjét. A dunántúli városok közül egyedül Pécs mutatott javulást, az élénkülés az ország keleti felében jobban érezhető volt (4. ábra).

A szabadalmi bejelentések elmúlt évtizedbeli regionális különbségeinek okait vizsgálva több olyan tényezö is megnevezhetô, amely vélhetỏen jelentős mértékben hozzájárult a szabadalmi bejelentések területi egyenlőtlenségeinek kialakulásához. A szabadalmi bejelentések nagyvárosi koncentrációinak (Budapest, Szeged, Debrecen) kialakulása mindenekelőtt azzal magyarázható, hogy a tudás a nagyvárosokban koncentrálódik. Az említett települések Magyarország legnagyobb tradicionális egyetemvárosai és kutatás-fejlesztési bázisai, a legjelentősebb hazai természettudományi, biológiai és orvostudományi központok. 
Smahó Melinda : Szabadalmak, szabadalmi bejelentések és területi innovativitás Magyarországon.

Tér és Társadalom 19. évf. 2005/3-4. 61-79. p.

\section{4. ÁBRA}

Szabadalmi bejelentések száma telepiilésenként (db), 2002

(Patent Applications in Settlements [Piece], 2002)

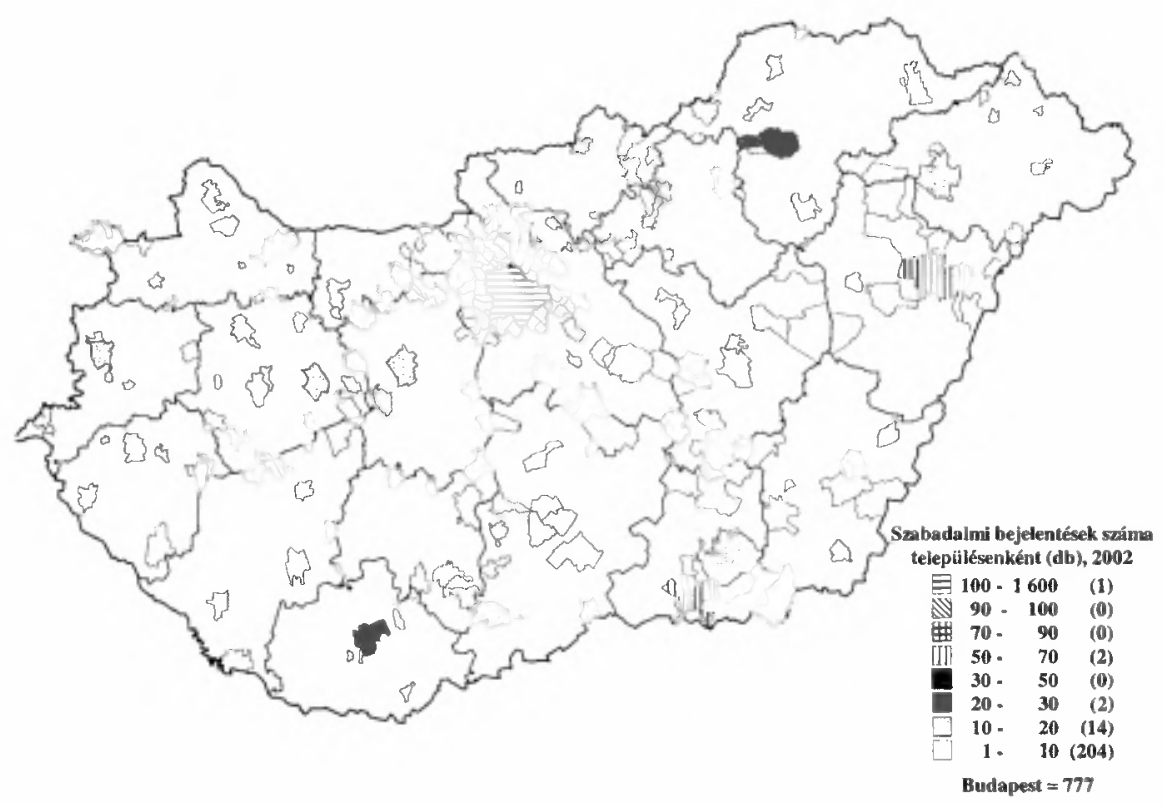

Forrás: Saját szerkesztés a Magyar Szabadalmi Hivatal adatai alapján.

A szabadalmi bejelentések számának területi alakulására, annak változására nagy hatással volt a $K+F$ szektorban végbement átalakulás, mindenekelött annak területi sajátosságai. Budapesten 1997 és 2001 között az ott elöállított GDP 1,5-1,9\%-át fordították kutatás-fejlesztésre, miközben az országos érték 0,78-1,03\% között mozgott. Vidéki viszonylatban Kelet-Magyarország két megyéje, Csongrád és Hajdú-Bihar esetében voltak kiemelkedők a GDP arányos kutatás-fejlesztési költségek. Mindez nagymértékben hozzájárult a föváros és az ország keleti fele vezetö pozíciójának kialakulásához és fennmaradásához. Budapest helyzetét tovább erősítette, hogy ott találhatók a legjelentősebb vállalati székhelyek, valamint az ország egyetlen technológiai parkja, amely az innovációorientált, szabadalmaztatási aktivitás szempontjából feltehetően releváns vállalkozásoknak ad otthont.

Jelentősen befolyásolta a szabadalmi bejelentések területi eloszlását az ipar szerkezetének, területi struktúrájának, tulajdonviszonyainak megváltozása. A magas szabadalmaztatási hajlandóságú iparágak - néhány területen napjainkig elhúzódó válsága, kapacitásainak leépuilése drasztikus csökkenést idézett eló az ezen ágazatokra specializálódott térségek szabadalmi bejelentéseinek számában. Magyarországon 2003-ban a gyógyszeripar, a szerves kémia, a gyógyászati, fogászati és kozmetikai készitmények szakterülete, a biokémia, a mezögazdaság és az épitöipar rendelkezik a legtöbb érvényes szabadalommal (Éves jelentés 2003). 2004-re némi 
Smahó Melinda : Szabadalmak, szabadalmi bejelentések és területi innovativitás Magyarországon.

Tér és Társadalom 19. évf. 2005/3-4. 61-79. p.

TÉT XIX. évf. 2005 @ 3-4

Szabadalmak, szabadalmi bejelentések ...

77

változás ált be a legtöbb érvényes szabadalommal rendelkező jparágak rangsorában: a gyógyszeripar és a biokémia továbbra is az élvonalban maradt, ezt követi nagyságrendekkel lemaradva a gépészet és a kémia (Éves jelentés 2004). A szabadalmaztatás szempontjából hazánkban ezek a legfontosabb iparágak, ennek következtében területi elhelyezkedésük, területi koncentrációjuk nagymértékben meghatározza a szabadalmi bejelentések forrásterületeit.

\section{Összegzés}

A szellemi tulajdon védelme és a szabadalom jogintézménye több évszázados múltra tekint vissza, közgazdasági hatásaikat illetően többféle elméleti megközelítés látott napvilágot. A védelem egyrészt kedvező hatást gyakorol az innováció ösztönzésére, másrészt a kizárólagos oltalom monopolhelyzetet, s ezáltal piaci hatékonytalanságot teremt. A szabadalmi oltalom a találmányok nyilvánosságra hozatalát nem minden esetben ösztönzi, bizonyos esetekben a felfedezések titokban tartása nagyobb előnyökkel jár.

A szabadalmi bejelentéseket - azok minden előnyével és hátrányával együtt - egy terület innovativitásának méröszámaként tekinthetjük. A szabadalmi bejelentések településsoros adatai lényegében a bejelentők számát tükrözik, $s$ ennélfogva földrajzi eloszlásukból a tudás, a humán erőforrás egyfajta megnyilvánulásának területi szerkezetére következtethetünk.

A szabadalmi bejelentések földrajzi eloszlásában kimutathatók az átmenet folyamatának lenyomatai. Magyarországon az elmúlt évtizedben jelentős visszaesés következett be a szabadalmi bejelentések számában, aminek föbb okai a kutatásfejlesztési ráfordítások és kapacitások drasztikus csökkenésében, a vállalati szerkezetátalakításban, valamint az életszínvonal csökkenésében keresendők. A változatlan áron számított kutatás-fejlesztési ráfordítások és a két évvel később benyújtott szabadalmi bejelentések száma között erős pozitív korreláció mutatható ki.

A szabadalmi bejelentések területi elhelyezkedése az átmenet egyes szakaszaiban differenciált képet mutat, több dimenzióban fedezhetók fel regionális különbségek. A város-vidék különbségek többszörösen is megnyilvánulnak, a városhierarchián belül nagyságrendbeli eltérések érzékelhetők. A legnagyobb koncentrációt mindvégig a főváros és agglomerációja jelentette, bár az elmúlt évtized folyamán bekövetkezett átstrukturálódás a vidéki városok javára történt. A vidéki városok közül a tradicionális egyetemvárosok emelkednek ki, amelyek - a főváros után - az ország legjelentősebb kutatás-fejlesztési központjai, tudáskoncentrációi.

A kelet-nyugati tagoltságot vizsgálva megállapítható, hogy a szabadalmi bejelentések tekintetében az elmúlt évtizedben egyértelmúen az ország keleti fele a meghatározó. Ez mindenekelött azzal magyarázható, hogy vidéki viszonylatban KeletMagyarország két megyéjében (Csongrád, Hajdú-Bihar) a legmagasabb a kutatásfejlesztési ráfordítások regionális GDP-hez viszonyított aránya. A szabadalmi bejelentések területi szerkezetét vélhetően nagymértékben befolyásolja a magas szabadalmaztatási hajlandóságú vállalatok, iparágak földrajzi elhelyezkedése, ám ennek igazolása további kutatásokat igényel. 
Smahó Melinda : Szabadalmak, szabadalmi bejelentések és területi innovativitás Magyarországon.

Tér és Társadalom 19. évf. 2005/3-4. 61-79. p.

\section{Jegyzetek}

${ }^{1}$ Köszönettel tartozom Szász Andrásnak, Dr. Rechnitzer Jánosnak és Dr. Döry Tibornak a tanulmány elkészítéséhez nyújtott segítségéért.

${ }^{2}$ Egy szabadalomnak átlagosan 1,5 tulajdonosa van.

${ }^{3}$ A szabadalmi törvény a nem magán találmányok esetében megkülönbözteti a szolgálati és az alkalmazotti találmány fogalmát. Eszerint „szolgálati találmány annak a találmánya, akinek munkaviszonyból folyó kötelessége, hogy a találmány tárgykörébe esö megoldásokat dolgozzon ki”, míg „alkalmazotti találmány annak a találmánya, aki, anélkủl, hogy ez munkaviszonyból eredö kötelessége lenne, olyan találmányt dolgoz ki, amelynek hasznosítása munkáltatója tevékenységi körébe tartozik". (2002. évi XXXIX. törvénnyel módosított, 1995. évi XXXIII. törvény, 9. §) Szolgálati találmány esetén „a szabadalom a feltaláló jogutódjaként a munkáltatót illeti meg", míg az alkalmazotti találmánynál a szabadalom a feltalálóé, a munkáltató azonban jogosult a találmány hasznosítására (2002. évi XXXIX. törvénnyel módosított, 1995. évi XXXIII. törvény, 10. \$).

${ }^{4}$ Magyarország 2003. január 1-jén csatlakozott az Európai Szabadalmi Egyezményhez, ami azt jelenti, hogy az európai szabadalmat igénylök Magyarország területére már nem közvetlenül (a Magyar Szabadalmi Hivatalnál tett bejelentéssel), hanem közvetetten kérnek védettséget, azaz európai szabadalmi bejelentésükben jelölik meg hazánkat.

\section{Irodalom}

A 2002. évi XXXIX törvénnyel módosított, 1995. évi XXXIII. tờvény.

Barta Gy. (2002) A magyar ipar területi folyamatai 1945-2000. Dialóg-Campus, Budapest-Pécs.

Basberg, B. (1987) Patents and the measurement of technological change: a survey of the literature. Research Policy. 2-4. 131-141. o,

Caniëls, M.C.J (2000) Knowledge Spillovers and Economic Growth. Regional Growth Differentials Across Europe. New Horizons in the Economics of Innovation. Edward Elgar, Cheltenham, UK, Northampton, MA, USA.

Carlton, D.W.-Perloff, J.M. (2003) Modern piacelmélet. Panem, Budapest.

Csiky P (1999) Szabadalom, újitás, védjegy. Hasznos tudnivalók a vállalkozáshoz. Kalangya Kkt., Budapest.

Döry T.-Mészáros R.-Rechnitzer J. (1998) Tudomány és regionalitás Magyarországon a 90-es években. - Tér és Társadalom. 3. 105-127. o.

Döry T.-Rechnitzer J. (2000) Regionális innovációs stratégiák. Oktatási Minisztérium, Budapest.

Éves jelentés 2003. Magyar Szabadalmi Hivatal, Budapest. 2004.

Éves jelentés 2004. Magyar Szabadalmi Hivatal, Budapest. 2005.

Greif, S. (2001) Patentgeographie. Die räumliche Struktur der Erfindungs-tätigkeit in Deutschland. Raumordnung und Raumforschung. 2-3. 142-153. o.

A gyógyszerpiac szabályozásának versenypolitikai kérdései. Versenyhivatali Füzetek, 6. szám. Gazdasági Versenyhivatal, Budapest. 2003.

A Magyar Iparjogvédelmi és Szerzői Jogi Egyesület keretében müködő munkabizottság jelentése a kutatási- fejlesztési tevékenység és a szabadalmi bejelentési aktivitás közötti kapcsolatról (2001) http://www.mie.org.hu, 2004. augusztus 5.

Menell, P.S. (1999) Intellectual Property: General Theories. Encyclopedia of Law \& Economics, http://encyclo.findlaw.com/

Meusburger, P. (1998) Bildungsgeographie. Wissen und Ausbildung in der räumlichen Dimension. Spektrum Akademischer Verlag, Heidelberg-Berlin.

Palugyai I. (2004) Szabadalomra oktatnak. - Népszabadság, 2004. szeptember 16.

Suarez-Villa, L. (1993) The Dynamics of Regional Invention and Innovation: Innovative Capacity and Regional Change in the Twentieth Century. - Geographical Analysis. 2. 147-164. o.

http://www.unkari.fi/magyarul/tudomCont.html

www.mszh.hu 
Smahó Melinda : Szabadalmak, szabadalmi bejelentések és területi innovativitás Magyarországon.

Tér és Társadalom 19. évf. 2005/3-4. 61-79. p.

TÉT XIX. évf. 2005 -3-4 Szabadalmak, szabadalmi bejelentések ... 79

\section{PATENTS, PATENT APPLICATIONS AND SPATIAL INNOVATIVENESS IN HUNGARY}

\section{MELINDA SMAHÓ}

On the one hand the study publishes the approaches connected to the intellectual property rights and patents, on the other hand it investigates the innovativeness of the Hungarian settlements by the number of patent applications. The aim of the analyses concerning the transition period is to discover the regional disparities and to explain their causes.

The study discovers a strong positive correlation between R\&D costs and patent applications submitting two years later, and shows regional disparities in more dimensions as well. In spite of the re-structuring in favour of rural cities, the leading role of the capital has remained through the last decade. There have been high differences in the town hierarchy, even inside of the county towns: actually some traditional university cities have outstood. Regarding the East-West relation, the east part of the country has been dominant. 